\title{
Impact of different treatments on chemical composition, physical, anti-nutritional, antioxidant characteristics and in vitro starch digestibility of green-kernel black bean flours
}

\author{
Ngoc Lieu LE ${ }^{1,2 *}$ (D), Thanh Thi Ha LE ${ }^{1,2}$, Nguyet Thi Minh NGUYEN ${ }^{3,4}$, Linh Tran Khanh VU ${ }^{3 *}$ (D)
}

\begin{abstract}
Green-kernel black bean (Vigna cylindrica (L.) Skeels) were processed with various treatments including soaking, roasting, cooking, autoclave and germination. The effects of these treatments on the chemical compostion, mineral, anti-nutrients, antioxidant and physical properties of the resultant flours were analyzed. The results indicate that green-kernel black bean was excellent sources of dietary fiber $(165.4 \mathrm{~g} / \mathrm{kg})$, magnesium $(2190 \mathrm{mg} / \mathrm{kg})$, anthocyanin $(791.6 \mathrm{mg} / \mathrm{kg})$ and phenolic compounds (4.4 g gallic acid equivalent $/ \mathrm{kg}$ ), which were virtually higher than those reported for other pulses. Among the studied processing methods, cooking and autoclave provided the most evident effects on all flour characteristics, where the water holing capacity was enhanced and the flour became brighter. In addition, the levels of anti-nutrients such as tannin, saponin and trypsin inhibitors remarkably reduced and hence the starch digestibility was improved. However, antioxidant compounds were degraded or lost, leading to lower antioxidant capacities in terms of 2,2-diphenyl-2-picrylhydrazyl hydrate (DPPH) free radical scavenging ability and ferric reducing antioxidant power (FRAP). On the other hand, germination resulted in lesser reduction of anti-nutrients but lesser losses of antioxidants and good starch digestibility. Meanwhile, roasting caused the least effects on flour characteristics but was still able to partially degrade anti-nutrients.
\end{abstract}

Keywords: Vigna cylindrica; anti-nutrient; dietary fiber; magnesium; anthocyanin; glycemic index.

Practical Application: Green-kernel black bean can be a healthy ingredient to develop cereal-based products.

\section{Introduction}

Green-kernel black bean, which belongs to the species of Vigna cylindrica (L.) Skeels, like many other pulses are excellent source of nutrients such as protein, dietary fiber, antioxidants and minerals. Due to their high density of these functional components, there has been association between pulse diets and lower risks of many diseases such as obesity, diabetes, heart disease and cancer (Ferreira et al., 2021). Although pulses are the main part of diet in India and certain southern America, their consumption is still limited in Northern America and Europe (Lascialfari et al., 2019). The possible causing factors include lengthened cooking duration, unfavorable taste and certain abdominal discomfort symptoms. In the attempt of tackling these issues and increasing pulse intake in human diet, food manufacturers have processed whole pulses to reduce anti-nutrient factors, prepared them into flours for convenient use, and employed pulse flours as ingredients to substitute low-protein flours (e.g. rice, corn, starch) for development of numerous cereal-based products and gluten-free products (Fujiwara et al., 2017; Pellegrini \& Agostoni, 2015).

Considering hard-to-cook characteristics and antinutritional factors of raw pulses, various softening and processing techniques have been explored, including soaking (Haileslassie et al., 2019; Li et al., 2020), roasting (Bi et al., 2021), cooking (Wiesinger et al., 2018), autoclaving (Escobedo et al., 2020) and germination (Haileslassie et al., 2019). Even though these processes provide different positive impacts on pulse quality in terms of improving the flavor, modifying the functionality, increasing starch digestibility and mineral bioaccessibility, other health beneficial compounds such as antioxidants may be partially lost or degraded. For example, Giusti et al. (2019) highlighted that cooking could reduce the content of heat-sensible bioactive compounds like anthocyanins but may favor the formation or release of simple phenolics from complexes. In addition, autoclaving was reported to increase protein content and starch digestibility while reduce the fiber content of Phaseolus vulgaris $\mathrm{L}$. bean (Escobedo et al., 2020). On the other hand, their effects may vary, depending the types of pulse and their variety. For example, proper conditions of germination and cooking could improve the calcium and zinc contents of Mastewal chickpea but no evident effectiveness was observed for Habru chickpea or Red Wolaita red dry bean (Haileslassie et al., 2019). In another study, microwave cooking led to higher phenolic content than boiling cooking for lentil but an opposite trend was achieved for faba bean and pea (Liu et al., 2020). Therefore, the need still exists to investigate the effects of different processing methods on nutritional values and functional properties of individual pulses. 
Although green-kernel black bean is popularly believed to have high level of nutrients and can prevent many diseases in Asian countries, limited research has been done and there have been no scientific reports on their chemical properties yet. Therefore, the purpose of this study is to investigate the physical, chemical, antinutritional, antioxidant and mineral characteristics and starch digestibility of green-kernel black bean flours pre-processed with various techniques such as soaking, roasting, common cooking, autoclaving and germination in comparison with those of raw one.

\section{Materials and methods}

\subsection{Materials and chemicals}

Green-kernel black bean was purchased from local distributors in Ho Chi Minh city. All chemicals and standards required were of analytical grade purchased from Sigma Aldrich or Merk. Enzymes for analyses of dietary fiber and starch digestibility were purchase from Megazyme.

\subsection{Sample preparation}

Black bean, which was sorted for regular shape and size, was cleaned and dried in an oven (Memmert UF260, Germany) at $70{ }^{\circ} \mathrm{C}$ until no weight change was recorded. The sample was then ground by a grinder ( $800 \mathrm{Y}$, China) and sieved at $0.075 \mathrm{~mm}$ (TBT, China). The obtained raw black bean powder was subsequently kept in cellophane bags and stored at $4{ }^{\circ} \mathrm{C}$ until analyses. The whole raw bean was also treated with different methods. Screening was done to select suitable condition for each treatment. The soaking process was carried by immersing bean into water with the ratio of 1:5 (w/v) at room temperature for $12 \mathrm{~h}$ for maximum water absorption. Such soaking condition was also applied prior to germination at room temperature for another $12 \mathrm{~h}$. The roasting procedure was conducted at $180^{\circ} \mathrm{C}$ for 20 min using a cafe roaster (Gene Cafe CBR-101, South Korea). In the cooking treatment, the mixture of bean in water with the ratio of 1:5 (w/v) was cooked for 30 min using an inox cooker (Fivestar, Vietnam). Similar bean:water ratio was used in autoclave (ALP CL-40M, Japan) treatment at $121^{\circ} \mathrm{C}$ for $5 \mathrm{~min}$. All treated bean samples were cleaned, dried, grinded, sieved and stored in the same procedure of raw bean flour.

\subsection{Analytical methods}

Moisture and chemical composition of all flour samples including protein, lipid, and dietary fiber were determined by
AOAC methods. Total carbohydrate content was determined by subtraction (European Union, 2009). The saponin and tannin contents were analyzed by the methods of Edewor et al. (2016) and Atanassova \& Christova-Bagdassarian (2009), respectively. Trypsin inhibitor activity was spectrophotometrically determined by the method of Shang et al. (2016) and the data were expressed as trypsin inhibitor units (TIUs) per gram of sample. Anthocyanin content was determined by the $\mathrm{pH}$ differential spectrometric method (Giusti \& Wrolstad, 2001), while total phenolic content (TPC) was measured using the Folin - Ciocalteu method (Jagtap \& Bapat, 2015). The antioxidant capacities were evaluated through 2,2-diphenyl-2picrylhydrazyl hydrate (DPPH) free radical scavenging ability (Le et al., 2021) and ferric reducing antioxidant power (FRAP) (Guo et al., 2003). The mineral contents were analyzed by performed by inductively coupled plasma mass spectrometry (Feitosa et al., 2018). Starch digestibility was accessed through hydrolysis index (HI) and glycemic index (GI), following the method of Zhang et al. (2019). Water holding capacity (WHC) and oil holding capacity (OHC) were measured by the method of Gupta et al. (2018). The color attributes including L, $\mathrm{a}^{\star}$ and $b^{\star}$ were measured by using a chroma meter (CR-400, Konica Minolta, Japan).

\subsection{Statistical analysis}

All the measurements were performed in triplicate and results were expressed as average value with standard deviation. All statistical analyses were performed by the software Minitab (version 18.1) with 95\% confident interval. The difference among samples were evaluated by one-way ANOVA and Tukey's comparison tests.

\section{Results and Discussion}

\subsection{Chemical composition}

Table 1 presents the chemical composition of raw and processed bean flours. The protein contents of all samples were not significantly different ( $\mathrm{p}>0.05$ ), except the autoclaved sample. Among the treatments, autoclave provided the highest level of heat treatment, which led to the high denaturation, solubility and partial degradation of proteins. With the presence of water in the autoclave treatment, these changes would cause the partial loss of the newly produced amino acids and nitrogenous compounds. The reduction in protein during high-heat cooking have also been

Table 1. Chemical composition of green-kernel black bean flour processed with different treatments.

\begin{tabular}{|c|c|c|c|c|c|}
\hline \multirow{2}{*}{ Sample } & Protein & Lipid & Ash & Total carbohydrate & Dietary fiber \\
\hline & $(\mathrm{g} / \mathrm{kg})$ & $(\mathrm{g} / \mathrm{kg})$ & $(\mathrm{g} / \mathrm{kg})$ & $(\mathrm{g} / \mathrm{kg})$ & $(\mathrm{g} / \mathrm{kg})$ \\
\hline Raw & $280.0 \pm 4.2^{\mathrm{a}}$ & $118.7 \pm 3.3^{b}$ & $40.9 \pm 1.5^{\mathrm{ab}}$ & $560.4 \pm 2.6^{\mathrm{d}}$ & $165.4 \pm 7.0^{\mathrm{b}}$ \\
\hline Soaked & $271.9 \pm 2.4^{\mathrm{a}}$ & $112.4 \pm 2.1^{\mathrm{b}}$ & $37.5 \pm 0.4^{\mathrm{b}}$ & $578.1 \pm 1.5^{\mathrm{c}}$ & $162.9 \pm 12.2^{\mathrm{b}}$ \\
\hline Roasted & $274.5 \pm 1.9^{\mathrm{a}}$ & $92.6 \pm 2.5^{c}$ & $41.5 \pm 1.9^{\mathrm{a}}$ & $591.5 \pm 3.9^{\mathrm{ab}}$ & $190.6 \pm 8.2^{\mathrm{ab}}$ \\
\hline Cooked & $275.4 \pm 3.4^{\mathrm{a}}$ & $110.6 \pm 2.3^{\mathrm{b}}$ & $32.5 \pm 1.3^{c}$ & $581.4 \pm 4.3^{\mathrm{bc}}$ & $205.2 \pm 3.8^{\mathrm{a}}$ \\
\hline Autoclaved & $260.4 \pm 3.7^{b}$ & $117.0 \pm 1.3^{\mathrm{b}}$ & $27.4 \pm 1.0^{\mathrm{d}}$ & $595.3 \pm 5.7^{\mathrm{a}}$ & $189.1 \pm 8.3^{\mathrm{ab}}$ \\
\hline Germinated & $271.5 \pm 3.4^{\mathrm{a}}$ & $134.2 \pm 5.8^{\mathrm{a}}$ & $38.8 \pm 0.9^{\mathrm{ab}}$ & $556.0 \pm 7.4^{\mathrm{d}}$ & $187.6 \pm 0.8^{\mathrm{ab}}$ \\
\hline
\end{tabular}

Note: dry basis. Different letters in the same column indicate significant differences $(\mathrm{p}<0.05)$. 
reported for other pulses such as navy bean (Kenar et al., 2020), chick peas, lentils, and kidney beans (Rehman \& Shah, 2005).

On the other hand, there were no significant differences in lipid content among samples except the roasted and germinated samples. Different from the previous reports which observed the increase in oil content of sesame (Makinde \& Akinoso, 2014) or maize (Oboh et al., 2010) after roasting, the lipid content of green-kernel black bean slightly decreased. This might be due to the differences in roasting conditions and pulse species. Roasting at high temperatures without water could cause the collapse and shrinkage of cell structures, which may limit the diffusion of oil into hexane during the lipid determination in this study. Meanwhile, germination signigicantly increased $(p<0.05)$ the fat content in green-kernel black bean. Sritongtae et al. (2017) observed the changes in the crude fat content of rice bean (Vigna umbellata) over germination time, where it increased more than two times after 6-hour germination while longer periods of germination (up to $24 \mathrm{~h}$ ) could significantly reduce the accumulated fat. According to Obizoba \& Egbuna (1992), in the early stage of seed development, seeds evolve with rapid synthesis of triglycerides while they use other energy sources (i.e. proteins or carbohydrates) for their metabolism. This could be the reason for the increase in fat content observed in this study.

Regarding ash content, a decreasing trend $(\mathrm{p}<0.05)$ was observed for cooked and autoclaved samples. The presence of water in combination with high temperatures of these two processing methods could lead to the partial loss of soluble salts. On the other hand, the dietary fiber of raw and processed green-kernel black beans ranged 162.9 to $205.2 \mathrm{~g} / \mathrm{kg}$, contributing approximately $30 \%$ of total carbohydrate ( 556.0 to $595.3 \mathrm{~g} / \mathrm{kg}$ ). These data imply green-kernel black beans could be a good source of dietary fiber, which was comparable or higher than the values reported for other pulses such as chickpea $(149 \mathrm{~g} / \mathrm{kg})$, lentil $(99 \mathrm{~g} / \mathrm{kg})$ and yellow pea $(173 \mathrm{~g} / \mathrm{kg}$ ) (Xu et al., 2019). Among the studied treatments, only autoclave led to a significant increment in dietary fiber. According to (Dundar \& Gocmen, 2013), high actoclaving temperatures had positive effects on the formation of resistant starch, which could avoid the digestion of enzymes. Therefore, the formed resistant starch could play the same function with dietary fiber and contribute to their content increase which was determined by the enzymatic digestion method. This increasing trend was observed for common bean (Phaseolus vulgaris L.) (Martín-Cabrejas et al., 2004) and chickpea starch (Polesi \& Sarmento, 2011).

\subsection{Minerals}

Table 2 presents the mineral contents of raw and processed bean flours. Green-kernel black bean can be considered excellent sources of certain essential minerals, contributing 40 to $100 \%$ of the RDA for zinc, magnesium, copper and iron in its cooked or processed products equivalent of $100 \mathrm{~g}$ dry weight, which is a reasonable serving size of food for humans (National Institutes of Health, 2018). Particularly, green-kernel black bean appeared to have a remarkably high level of magnesium, which were higher than the data reported for many other pulses such as chickpea, field pea, lentil (Ray et al., 2014), pea, and kidney bean (Alonso et al., 2001). On the other hand, Table 2 reveals that roasting caused no significant effects $(p>0.05)$ on mineral contents while soaking significantly reduced $(\mathrm{p}<0.05)$ the levels of all studied minerals, except iron. These losses may be attributed to their leaching out the discarded water. These observations are in close agreement with the results of ElMaki et al. (2007) for white bean. The presence of water in cooking and autoclave methods may also be the reason for the losses of copper and magnesium $(p<0.05)$. Meanwhile, germination with the short period of $12 \mathrm{~h}$ nearly did not significantly $(\mathrm{p}>0.05)$ alter the mineral levels.

\subsection{Anti-nutrients and starch digestibility}

The presence of anti-nutrients in pulses is one of the main factors limiting their use. These substances could interfere the bioavailability of micronutrients and digestibility of macronutrients (Rehman \& Shah, 2005). Therefore, understanding their level changes with processing is crucial in the development of pulse products. In this study, the investigated anti-nutrients of greenkernel black bean include tannin, saponin and trypsin inhibitor. Table 3 reveals that all the studied treatments could reduce the levels of anti-nutrients but with different extents. Thermal treatments combined with water (i.e. cooking and autoclave) were demonstrated to provide the highest efficiency, reducing tannin and saponin contents approximately $65 \%$ and $28 \%$, respectively; and virtually inactivating trypsin inhibitors to an undetected level. These treatments also led to higher HI and GI values of the flours, indicating better starch digestibility. The improvement in starch digestibility could be due to the heat-induced starch gelatinization and destruction of antinutrients (Rehman \& Shah, 2005). These results were in close consistence with those reported by the majority of previous studies (Abbas \& Ahmad, 2018; Adeparusi, 2001). On the other

Table 2. Mineral contents of green-kernel black bean flour processed with different treatments.

\begin{tabular}{lcllll}
\hline \multicolumn{1}{c}{ Sample } & $\mathrm{Ca}(\mathrm{mg} / \mathrm{kg})$ & $\mathrm{Cu}(\mathrm{mg} / \mathrm{kg})$ & $\mathrm{Fe}(\mathrm{mg} / \mathrm{kg})$ & $\mathrm{Mg}(\mathrm{mg} / \mathrm{kg})$ & $\mathrm{Zn}(\mathrm{mg} / \mathrm{kg})$ \\
\hline Raw & $597 \pm 59^{\mathrm{ab}}$ & $9.49 \pm 0.01^{\mathrm{a}}$ & $63.4 \pm 5.2^{\mathrm{a}}$ & $2190 \pm 50^{\mathrm{a}}$ & $41.4 \pm 1.0^{\mathrm{ab}}$ \\
Soaked & $558 \pm 11^{\mathrm{b}}$ & $8.69 \pm 0.08^{\mathrm{b}}$ & $61.9 \pm 1.0^{\mathrm{a}}$ & $1918 \pm 13^{\mathrm{b}}$ & $37.2 \pm 0.2^{\mathrm{c}}$ \\
Roasted & $632 \pm 9^{\mathrm{ab}}$ & $9.40 \pm 0.16^{\mathrm{a}}$ & $65.7 \pm 0.7^{\mathrm{a}}$ & $2213 \pm 59^{\mathrm{a}}$ & $42.4 \pm 0.5^{\mathrm{a}}$ \\
Cooked & $672 \pm 6^{\mathrm{a}}$ & $8.34 \pm 0.16^{\mathrm{b}}$ & $61.5 \pm 1.6^{\mathrm{a}}$ & $1725 \pm 8^{\mathrm{c}}$ & $41.9 \pm 0.2^{\mathrm{ab}}$ \\
Autoclaved & $638 \pm 6^{\mathrm{ab}}$ & $8.25 \pm 0.08^{\mathrm{b}}$ & $56.1 \pm 1.0^{\mathrm{a}}$ & $1699 \pm 21^{\mathrm{c}}$ & $41.8 \pm 0.3^{\mathrm{ab}}$ \\
Germinated & $626 \pm 10^{\mathrm{ab}}$ & $9.02 \pm 0.01^{\mathrm{ab}}$ & $59.9 \pm 5.4^{\mathrm{a}}$ & $2035 \pm 1^{\mathrm{b}}$ & $39.9 \pm 0.6^{\mathrm{b}}$ \\
\hline
\end{tabular}

Note: dry basis. Different letters in the same column indicate significant differences $(\mathrm{p}<0.05)$. 
hand, the treatments with the single factor of water or heat (i.e. soaking or roasting) could also lower anti-nutrients with much lesser extent and resulted in lower HI and GI values of flours, implying no evident effects on their starch digestibility. Meanwhile, germination caused higher reduction of tannin and trypsin inhibitor than soaking, which was consistent with the report of Haileslassie et al. (Haileslassie et al., 2019) for red dry bean and chickpea. The HI and GI values of the germinated bean flour were significantly higher $(\mathrm{p}<0.05)$ than those of the raw one. Similar improvement was also observed for other pulses reported by Bravo et al. (Bravo et al., 1998). During germination, many enzymes are activated, resulting in the hydrolysis of numerous components including proteins, carbohydrates and high-molecular-weight phenolic compounds (i.e. tannins) (Kumari, et al., 2015), which could justify the decreasing trend in anti-nutrients and the increasing trend in starch digestibility.

\subsection{Antioxidant properties}

Pulses are also good source of phenolic compounds, where anthocyanins, a subgroup of phenolic compounds, primarily exist in the seed coat of pulses. These compounds have been demonstrated beneficial to health with their anti-cancer and antiinflammation properties (Singh et al., 2017). They also exhibit antioxidant capacities through the mechanism of free radical scavenging or metal reducing ability, which could potentially reduce the risk of cancer and other diseases. In this study, the contents of anthocyanins and phenolic compounds were hence analyzed. The antioxidant capacities were evaluated through DPPH free radical scavenging and ferric reducing power. Table 4 illustrates that green-kernel black bean had high amounts of total phenolic content (TPC) with the value of $4.4 \mathrm{~g} \mathrm{GAE} / \mathrm{kg}$ for the raw flour. This number was higher than those reported for lentil, cowpea, faba bean, chickpea, soybean, runner bean, common bean and pea (Lafarga et al., 2019), which ranged from 0.13 to
$0.37 \mathrm{~g} \mathrm{GAE} / \mathrm{kg}$. Similarly, its anthocyanin content of $791.6 \mathrm{mg} / \mathrm{kg}$ was considered high as compared with those reported for common bean (130-320 g/kg) (Oomah et al., 2005), chickpea $(15 \mathrm{mg} / \mathrm{kg})$, lentil $(36 \mathrm{mg} / \mathrm{kg})$ and Mexican black bean $(48 \mathrm{mg} / \mathrm{kg})$ (Silva-Cristobal et al., 2010). As the result, its antioxidant capacities by DPPH and FRAP measurements were remarkably high, which were $13.4 \mathrm{mmol} \mathrm{TE} / \mathrm{kg}$ and $338 \mathrm{mmol} \mathrm{FeSO}_{4} / \mathrm{kg}$, respectively. All the studied treatments significantly reduced $(\mathrm{p}<0.05)$ anthocyanin content and TPC and hence antioxidant capacities, where autoclave and roasting caused the highest and lowest losses, respectively. These data imply that the anthocyanins and phenolics in green-kernel black bean were highly water-soluble and heat-labile. It is noticed that germination actually increased the TPC value from 2.35 to $3.56 \mathrm{~g} \mathrm{GAE} / \mathrm{kg}$ since soaking was also carried out before germination. The increase in TPC during germination might be due to the action of actived enzymes involved in the biosynthesis of small-molecule-weight phenolic compounds from high-molecular-weight polyphenols like tannins (Drewnowski \& Gomez-Carneros, 2000). The increment in TPC and antioxidant capacities after germination was also observed for other pulses such as mung bean (Wongsiri et al., 2015) and rice bean (Sritongtae et al., 2017).

\subsection{Physical properties}

Table 5 present the water and oil holding capacities and color attributes of flours. All the studied treatments did not significantly change the oil holding capacity $(\mathrm{OHC})(\mathrm{p}>0.05)$ which ranged from 1.08 to $1.24 \mathrm{~g}$ oil $/ \mathrm{g}$ flour. Meanwhile, heat-involved treatments including roasting, cooking and autoclave significantly increased water holding capacity (WHC) where the WHC value of the roasted sample was lower than those of other two. The increase in WHC may be attributed to the remarkable damage of starch induced by thermal gelatinization, and denaturation and disscociation of the protein (Jogihalli et al., 2017). On the other hand, the color

Table 3. Anti-nutrient factors, hydrolysis and glycemix indices (HI and GI) of green-kernel black bean flour processed with different treatments.

\begin{tabular}{|c|c|c|c|c|c|}
\hline \multirow{2}{*}{ Sample } & Tannin & Saponin & Trypsin inhibitor & \multirow{2}{*}{$\mathrm{HI}$} & \multirow{2}{*}{ GI } \\
\hline & $(\mathrm{g} / \mathrm{kg})$ & $(\mathrm{g} / \mathrm{kg})$ & (TUI/g) & & \\
\hline Raw & $22.7 \pm 0.2^{\mathrm{a}}$ & $38.2 \pm 0.8^{\mathrm{a}}$ & $9500 \pm 406^{\mathrm{a}}$ & $72.7 \pm 3.4^{\mathrm{c}}$ & $79.6 \pm 1.9^{c}$ \\
\hline Soaked & $16.0 \pm 0.1^{\mathrm{b}}$ & $34.2 \pm 0.7^{\mathrm{b}}$ & $4229 \pm 68^{\mathrm{b}}$ & $66.3 \pm 0.7^{\mathrm{d}}$ & $76.1 \pm 0.4^{\mathrm{d}}$ \\
\hline Roasted & $13.0 \pm 0.2^{\mathrm{d}}$ & $30.3 \pm 1.0^{\mathrm{c}}$ & $3246 \pm 166^{c}$ & $68.7 \pm 3.3^{\mathrm{d}}$ & $77.4 \pm 1.8^{\mathrm{d}}$ \\
\hline Cooked & $8.0 \pm 0.2^{\mathrm{e}}$ & $27.8 \pm 1.0^{\mathrm{d}}$ & $\mathrm{ND}$ & $80.3 \pm 3.5^{b}$ & $83.8 \pm 1.9^{\mathrm{b}}$ \\
\hline Autoclaved & $7.0 \pm 0.1^{\mathrm{f}}$ & $26.8 \pm 0.1^{\mathrm{d}}$ & ND & $87.5 \pm 3.7^{\mathrm{a}}$ & $87.7 \pm 2.0^{\mathrm{a}}$ \\
\hline Germinated & $15.7 \pm 0.1^{\mathrm{c}}$ & $37.4 \pm 0.2^{\mathrm{a}}$ & $2808 \pm 104^{\mathrm{d}}$ & $81.9 \pm 3.3^{\mathrm{ab}}$ & $84.7 \pm 1.8^{\mathrm{ab}}$ \\
\hline
\end{tabular}

Note: dry basis; ND: not detected. Different letters in the same column indicate significant differences $(\mathrm{p}<0.05)$.

Table 4. Anthocyanin and total phenolic content, and antioxidant capacities of green-kernel black bean flour processed with different treatments.

\begin{tabular}{|c|c|c|c|c|}
\hline \multirow{2}{*}{ Sample } & Anthocyanin & TPC & $\mathrm{DPPH}$ & FRAP \\
\hline & $(\mathrm{mg} / \mathrm{kg})$ & (g GAE $/ \mathrm{kg})$ & $(\mathrm{mmol} \mathrm{TE} / \mathrm{kg})$ & $\left(\mathrm{mmol} \mathrm{FeSO}_{4} / \mathrm{kg}\right)$ \\
\hline Raw & $791.6 \pm 75.1^{a}$ & $4.40 \pm 0.27^{\mathrm{a}}$ & $13.41 \pm 1.13^{\mathrm{a}}$ & $337.7 \pm 12.8^{\mathrm{a}}$ \\
\hline Soaked & $296.8 \pm 15.1^{\mathrm{b}}$ & $2.35 \pm 0.07^{\mathrm{c}}$ & $5.97 \pm 0.19^{d}$ & $148.4 \pm 3.9^{\mathrm{d}}$ \\
\hline Roasted & $661.2 \pm 41.5^{c}$ & $4.11 \pm 0.01^{\mathrm{a}}$ & $11.14 \pm 0.12^{\mathrm{b}}$ & $296.4 \pm 0.5^{\mathrm{b}}$ \\
\hline Cooked & $77.3 \pm 4.9^{\mathrm{d}}$ & $1.88 \pm 0.12^{\mathrm{d}}$ & $5.72 \pm 0.08^{\mathrm{d}}$ & $138.9 \pm 8.8^{\mathrm{d}}$ \\
\hline Autoclaved & $55.9 \pm 4.6^{\mathrm{d}}$ & $1.61 \pm 0.20^{\mathrm{d}}$ & $4.92 \pm 0.56^{\mathrm{d}}$ & $111.0 \pm 6.4^{\mathrm{e}}$ \\
\hline Germinated & $232.7 \pm 19.3^{\mathrm{e}}$ & $3.56 \pm 0.11^{\mathrm{b}}$ & $7.72 \pm 0.36^{c}$ & $188.7 \pm 10.6^{c}$ \\
\hline
\end{tabular}

Note: dry basis; GAE: gallic acid equivalent; TE: Trolox equivalent. Different letters in the same column indicate significant differences $(\mathrm{p}<0.05)$. 
Table 5. Water and oil holding capacities and color attributes of green-kernel black bean flour processed with different treatments.

\begin{tabular}{|c|c|c|c|c|c|}
\hline \multirow{2}{*}{ Sample } & WHC & $\mathrm{OHC}$ & \multirow{2}{*}{$\mathrm{L}$} & \multirow{2}{*}{$a^{*}$} & \multirow{2}{*}{$b^{*}$} \\
\hline & (g water/g sample) & (g oil/g sample) & & & \\
\hline Raw & $1.02 \pm 0.09^{c}$ & $1.16 \pm 0.12^{\mathrm{a}}$ & $50.25 \pm 0.33^{\mathrm{a}}$ & $-1.47 \pm 0.05^{\mathrm{f}}$ & $6.75 \pm 0.13^{c}$ \\
\hline Soaked & $0.94 \pm 0.15^{c}$ & $1.24 \pm 0.08^{\mathrm{a}}$ & $49.93 \pm 0.58^{\mathrm{a}}$ & $-1.02 \pm 0.05^{\mathrm{e}}$ & $7.16 \pm 0.17^{\mathrm{b}}$ \\
\hline Roasted & $1.50 \pm 0.18^{\mathrm{b}}$ & $1.08 \pm 0.04^{\mathrm{a}}$ & $45.81 \pm 0.88^{\mathrm{b}}$ & $2.82 \pm 0.06^{\mathrm{b}}$ & $11.93 \pm 0.16^{\mathrm{a}}$ \\
\hline Cooked & $1.95 \pm 0.11^{\mathrm{a}}$ & $1.20 \pm 0.12^{\mathrm{a}}$ & $38.81 \pm 1.32^{\mathrm{c}}$ & $1.32 \pm 0.09^{c}$ & $4.83 \pm 0.05^{\mathrm{e}}$ \\
\hline Autoclaved & $1.91 \pm 0.04^{\mathrm{a}}$ & $1.10 \pm 0.05^{\mathrm{a}}$ & $31.00 \pm 0.38^{\mathrm{d}}$ & $4.78 \pm 0.06^{\mathrm{a}}$ & $5.75 \pm 0.05^{\mathrm{d}}$ \\
\hline Germinated & $1.11 \pm 0.03^{c}$ & $1.20 \pm 0.11^{\mathrm{a}}$ & $49.50 \pm 2.09^{\mathrm{a}}$ & $0.18 \pm 0.06^{\mathrm{d}}$ & $6.82 \pm 0.30^{\mathrm{bc}}$ \\
\hline
\end{tabular}

Note: dry basis. Different letters in the same column indicate significant differences $(\mathrm{p}<0.05)$.

analysis indicates that heat-involved treatments significantly enhanced the lightness (with the reduction in $\mathrm{L}$ value) which was partially ascribed to the dramatic loss of dark anthocyanins in the black seed coat. Meanwhile, the negative value of $\mathrm{a}^{\star}$ for the raw flour indicated toward green. All treatments except soaking turned the $\mathrm{a}^{*}$ value into positive, specifying the tendency toward red. All samples had positive $b^{*}$ values, designating to be inclining toward yellow. Particularly, the highest $b^{*}$ value of roasted sample may imply the possible browning effect or pigment transformation during roasting.

\section{Conclusions}

Our findings confirm that green-kernel black bean was an excellent source of nutrients, particularly dietary fiber, minerals and antoxidants. Regarding the presence of anti-nutrients in the pulse, the combination of water and heat in cooking and autoclave was the efficient ways, even able to completely eliminate trypsin inhibitors. However, in consideration of anthocyanin, total phenolic content and antioxidant capacities, roasting seemed to be more acceptable with its ability to partially degrade antinutrients. On the other hand, germination also led milder effects on antioxidant properties than cooking and autoclave but still provided good starch digestibility. The study suggests that the processed green-kernel black bean flour could be considered as a healthy and suitable ingredient for food industry to develop cereal-based products and gluten-free products.

\section{Acknowledgements}

This research is funded by Vietnam National University HoChiMinh City (VNU-HCM) under grant number C2019-28-08.

\section{References}

Abbas, Y., \& Ahmad, A. (2018). Impact of processing on nutritional and anti-nutritional factors of legumes: a review. Annals Food Science and Technology, 19(2), 199-215.

Adeparusi, E. (2001). Effect of processing on the nutrients and antinutrients of lima bean (Phaseolus lunatus L.) flour. Food, 45(2), 94-96. http://dx.doi.org/10.1002/1521-3803(20010401)45:2<94::AIDFOOD94>3.0.CO;2-E.

Alonso, R., Rubio, L., Muzquiz, M., \& Marzo, F. (2001). The effect of extrusion cooking on mineral bioavailability in pea and kidney bean seed meals. Animal Feed Science and Technology, 94(1-2), 1-13. http://dx.doi.org/10.1016/S0377-8401(01)00302-9.

Atanassova, M., \& Christova-Bagdassarian, V. (2009). Determination of tannins content by titrimetric method for comparison of different plant species. Journal of the University of Chemical Technology and Metallurgy, 44(4), 413-415.

Bi, S., Wang, A., Lao, F., Shen, Q., Liao, X., Zhang, P., \& Wu, J. (2021). Effects of frying, roasting and boiling on aroma profiles of adzuki beans (Vigna angularis) and potential of adzuki bean and millet flours to improve flavor and sensory characteristics of biscuits. Food Chemistry, 339, 127878. http://dx.doi.org/10.1016/j. foodchem.2020.127878. PMid:32866702.

Bravo, L., Siddhuraju, P., \& Saura-Calixto, F. (1998). Effect of various processing methods on the in vitro starch digestibility and resistant starch content of Indian pulses. Journal of Agricultural and Food Chemistry, 46(11), 4667-4674. http://dx.doi.org/10.1021/jf980251f.

Drewnowski, A., \& Gomez-Carneros, C. (2000). Bitter taste, phytonutrients, and the consumer: a review. The American Journal of Clinical Nutrition, 72(6), 1424-1435. http://dx.doi.org/10.1093/ ajcn/72.6.1424. PMid:11101467.

Dundar, A. N., \& Gocmen, D. (2013). Effects of autoclaving temperature and storing time on resistant starch formation and its functional and physicochemical properties. Carbohydrate Polymers, 97(2), 764-771. http://dx.doi.org/10.1016/j.carbpol.2013.04.083. PMid:23911513.

Edewor, T. I., Owa, S. O., Ologan, A. O., \& Akinfemi, F. (2016). Quantitative determination of the saponin content and GC-MS study of the medicinal plant Cassytha filiformis (linn.) leaves. Journal of Coastal Life Medicine, 4(2), 154-156. http://dx.doi.org/10.12980/ jclm.4.2016j5-210.

ElMaki, H. B., AbdelRahaman, S. M., Idris, W. H., Hassan, A. B., Babiker, E. E., \& El Tinay, A. H. (2007). Content of antinutritional factors and $\mathrm{HCl}$-extractability of minerals from white bean (Phaseolus vulgaris) cultivars: Influence of soaking and/or cooking. Food Chemistry, 100(1), 362-368. http://dx.doi.org/10.1016/j.foodchem.2005.09.060.

Escobedo, A., Loarca-Piña, G., Gaytan-Martínez, M., Orozco-Avila, I., \& Mojica, L. (2020). Autoclaving and extrusion improve the functional properties and chemical composition of black bean carbohydrate extracts. Journal of Food Science, 85(9), 2783-2791. http://dx.doi.org/10.1111/1750-3841.15356. PMid:32776549.

European Union. (2009, February 26). Commission Regulations (EC) No 152/2009 of 27 January 2009 laying down the methods of sampling and analysis for the official control of feed. Official Journal of the European Community, L54: 1, 130.

Feitosa, S., Greiner, R., Meinhardt, A.-K., Müller, A., Almeida, D. T., \& Posten, C. (2018). Effect of traditional household processes on iron, zinc and copper bioaccessibility in black bean (Phaseolus 
vulgaris L.). Foods, 7(8), 123. http://dx.doi.org/10.3390/foods7080123. PMid:30065167.

Ferreira, H., Vasconcelos, M., Gil, A. M., \& Pinto, E. (2021). Benefits of pulse consumption on metabolism and health: A systematic review of randomized controlled trials. Critical Reviews in Food Science and Nutrition, 61(1), 85-96. http://dx.doi.org/10.1080/10408398.2020.1 716680. PMid:31983216.

Fujiwara, N., Hall, C., \& Jenkins, A. L. (2017). Development of low glycemic index (GI) foods by incorporating pulse ingredients into cereal-based products: Use of in vitro screening and in vivo methodologies. Cereal Chemistry, 94(1), 110-116. http://dx.doi. org/10.1094/CCHEM-04-16-0119-FI.

Giusti, F., Capuano, E., Sagratini, G., \& Pellegrini, N. (2019). A comprehensive investigation of the behaviour of phenolic compounds in legumes during domestic cooking and in vitro digestion. Food Chemistry, 285, 458-467. http://dx.doi.org/10.1016/j.foodchem.2019.01.148. PMid:30797370.

Giusti, M. M., \& Wrolstad, R. E. (2001). Characterization and measurement of anthocyanins by UV-visible spectroscopy. Current Protocols in Food Analytical Chemistry, (1), F1. 2.1-F1.2.13. http:// dx.doi.org/10.1002/0471142913.faf0102s00.

Guo, C., Yang, J., Wei, J., Li, Y., Xu, J., \& Jiang, Y. (2003). Antioxidant activities of peel, pulp and seed fractions of common fruits as determined by FRAP assay. Nutrition Research, 23(12), 1719-1726. http://dx.doi.org/10.1016/j.nutres.2003.08.005.

Gupta, S., Chhabra, G. S., Liu, C., Bakshi, J. S., \& Sathe, S. K. (2018). Functional properties of select dry bean seeds and flours. Journal of Food Science, 83(8), 2052-2061. http://dx.doi.org/10.1111/17503841.14213. PMid:30044496.

Haileslassie, H. A., Henry, C. J., \& Tyler, R. T. (2019). Impact of pretreatment (soaking or germination) on nutrient and anti-nutrient contents, cooking time and acceptability of cooked red dry bean (Phaseolus vulgaris L.) and chickpea (Cicer arietinum L.) grown in Ethiopia. International Journal of Food Science \& Technology, 54(8), 2540-2552. http://dx.doi.org/10.1111/ijfs.14165.

Jagtap, U. B., \& Bapat, V. A. (2015). Phenolic composition and antioxidant capacity of wine prepared from custard apple (Annona squamosa L.) fruits. Journal of Food Processing and Preservation, 39(2), 175-182. http://dx.doi.org/10.1111/jfpp.12219.

Jogihalli, P., Singh, L., \& Sharanagat, V. S. (2017). Effect of microwave roasting parameters on functional and antioxidant properties of chickpea (Cicer arietinum). Lebensmittel-Wissenschaft + Technologie, 79, 223-233. http://dx.doi.org/10.1016/j.lwt.2017.01.047.

Kenar, J. A., Felker, F. C., Singh, M., Byars, J. A., Berhow, M. A., Bowman, M. J., \& Winkler-Moser, J. K. (2020). Comparison of composition and physical properties of soluble and insoluble navy bean flour components after jet-cooking, soaking, and cooking. LWT, 130, 109765. http://dx.doi.org/10.1016/j.lwt.2020.109765.

Kumari, S., Krishnan, V., \& Sachdev, A. (2015). Impact of soaking and germination durations on antioxidants and anti-nutrients of black and yellow soybean (Glycine max. L) varieties. Journal of Plant Biochemistry and Biotechnology, 24(3), 355-358. http://dx.doi. org/10.1007/s13562-014-0282-6.

Lafarga, T., Villaró, S., Bobo, G., Simó, J., \& Aguiló-Aguayo, I. (2019). Bioaccessibility and antioxidant activity of phenolic compounds in cooked pulses. International Journal of Food Science \& Technology, 54(5), 1816-1823. http://dx.doi.org/10.1111/ijfs.14082.

Lascialfari, M., Magrini, M.-B., \& Triboulet, P. (2019). The drivers of product innovations in pulse-based foods: insights from case studies in France, Italy and USA. Journal of Innovation Economics Management, 1(1), 111-143. http://dx.doi.org/10.3917/jie.028.0111.
Le, T. T. H., Vu, L. T. K., \& Le, N. L. (2021). Effects of membrane pore size and transmembrane pressure on ultrafiltration of red-fleshed dragon fruit (Hylocereus polyrhizus) juice. Journal of Chemical Technology and Biotechnology, 96(6), 1561-1572. http://dx.doi. org/10.1002/jctb.6672.

Li, P., Li, Y., Wang, L., Zhang, H., Qi, X., \& Qian, H. (2020). Study on water absorption kinetics of black beans during soaking. Journal of Food Engineering, 283, 110030. http://dx.doi.org/10.1016/j. jfoodeng.2020.110030.

Liu, Y., Ragaee, S., Marcone, M. F., \& Abdel-Aal, E.-S. M. (2020). Composition of phenolic acids and antioxidant properties of selected pulses cooked with different heating conditions. Foods, 9(7), 908. http://dx.doi.org/10.3390/foods9070908. PMid:32664208.

Makinde, F. M., \& Akinoso, R. (2014). Comparison between the nutritional quality of flour obtained from raw, roasted and fermented sesame (Sesamum indicum L.) seed grown in Nigeria. Acta Scientiarum Polonorum. Technologia Alimentaria, 13(3), 309-319. http://dx.doi. org/10.17306/J.AFS.2014.3.9. PMid:24887946.

Martín-Cabrejas, M. A., Sanfiz, B., Vidal, A., Mollá, E., Esteban, R., \& López-Andréu, F. J. (2004). Effect of fermentation and autoclaving on dietary fiber fractions and antinutritional factors of beans (Phaseolus vulgaris L.). Journal of Agricultural and Food Chemistry, 52(2), 261-266. http://dx.doi.org/10.1021/jf034980t. PMid:14733506.

National Institutes of Health - NIH. (2018). Nutrient recommendations: dietary reference intakes (DRI). Bethesda: NIH.

Obizoba, I. C., \& Egbuna, H. I. (1992). Effect of germination and fermentation on the nutritional quality of bambara nut (Voandzeia subterranea L. Thouars) and its product (milk). Plant Foods for Human Nutrition, 42(1), 13-23. http://dx.doi.org/10.1007/BF02196068. PMid:1546053.

Oboh, G., Ademiluyi, A. O., \& Akindahunsi, A. A. (2010). The effect of roasting on the nutritional and antioxidant properties of yellow and white maize varieties. International Journal of Food Science \& Technology, 45(6), 1236-1242. http://dx.doi.org/10.1111/j.1365-2621.2010.02263.x.

Oomah, B. D., Cardador-Martínez, A., \& Loarca-Piña, G. (2005). Phenolics and antioxidative activities in common beans (Phaseolus vulgaris L). Journal of the Science of Food and Agriculture, 85(6), 935-942. http://dx.doi.org/10.1002/jsfa.2019.

Pellegrini, N., \& Agostoni, C. (2015). Nutritional aspects of gluten-free products. Journal of the Science of Food and Agriculture, 95(12), 2380-2385. http://dx.doi.org/10.1002/jsfa.7101. PMid:25615408.

Polesi, L. F., \& Sarmento, S. B. S. (2011). Structural and physicochemical characterization of RS prepared using hydrolysis and heat treatments of chickpea starch. Stärke, 63(4), 226-235. http://dx.doi.org/10.1002/ star.201000114.

Ray, H., Bett, K., Tar'an, B., Vandenberg, A., Thavarajah, D., \& Warkentin, T. (2014). Mineral micronutrient content of cultivars of field pea, chickpea, common bean, and lentil grown in Saskatchewan, Canada. Crop Science, 54(4), 1698-1708. http://dx.doi.org/10.2135/ cropsci2013.08.0568.

Rehman, Z., \& Shah, W. (2005). Thermal heat processing effects on antinutrients, protein and starch digestibility of food legumes. Food Chemistry, 91(2), 327-331. http://dx.doi.org/10.1016/j.foodchem.2004.06.019.

Shang, R., Wu, H., Guo, R., Liu, Q., Pan, L., Li, J., Hu, Z., \& Chen, C. (2016). The diversity of four anti-nutritional factors in common bean. Horticultural Plant Journal, 2(2), 97-104. http://dx.doi. org/10.1016/j.hpj.2016.06.001.

Silva-Cristobal, L., Osorio-Díaz, P., Tovar, J., \& Bello-Pérez, L. (2010). Chemical composition, carbohydrate digestibility, and antioxidant capacity of 
cooked black bean, chickpea, and lentil Mexican varieties Composición química, digestibilidad de carbohidratos, y capacidad antioxidante de variedades mexicanas cocidas de frijol negro, garbanzo, y lenteja. CYTA: Journal of Food, 8(1), 7-14. http://dx.doi.org/10.1080/19476330903119218.

Singh, B., Singh, J. P., Kaur, A., \& Singh, N. (2017). Phenolic composition and antioxidant potential of grain legume seeds: A review. Food Research International, 101, 1-16. http://dx.doi.org/10.1016/j. foodres.2017.09.026. PMid:28941672.

Sritongtae, B., Sangsukiam, T., Morgan, M. R., \& Duangmal, K. (2017). Effect of acid pretreatment and the germination period on the composition and antioxidant activity of rice bean (Vigna umbellata). Food Chemistry, 227, 280-288. http://dx.doi.org/10.1016/j. foodchem.2017.01.103. PMid:28274433.

Wiesinger, J. A., Cichy, K. A., Tako, E., \& Glahn, R. P. (2018). The fast cooking and enhanced iron bioavailability properties of the Manteca yellow bean (Phaseolus vulgaris L.). Nutrients, 10(11), 1609. http:// dx.doi.org/10.3390/nu10111609. PMid:30388772.
Wongsiri, S., Ohshima, T., \& Duangmal, K. (2015). Chemical composition, amino acid profile and antioxidant activities of germinated mung beans (Vigna radiata). Journal of Food Processing and Preservation, 39(6), 1956-1964. http://dx.doi. org/10.1111/jfpp.12434.

Xu, M., Jin, Z., Simsek, S., Hall, C., Rao, J., \& Chen, B. (2019). Effect of germination on the chemical composition, thermal, pasting, and moisture sorption properties of flours from chickpea, lentil, and yellow pea. Food Chemistry, 295, 579587. http://dx.doi.org/10.1016/j.foodchem.2019.05.167. PMid:31 174798.

Zhang, Y., Zhang, Y., Li, B., Wang, X., Xu, F., Zhu, K., Tan, L., Dong, W., Chu, Z., \& Li, S. (2019). In vitro hydrolysis and estimated glycemic index of jackfruit seed starch prepared by improved extrusion cooking technology. International Journal of Biological Macromolecules, 121, 1109-1117. http://dx.doi.org/10.1016/j.ijbiomac.2018.10.075. PMid:30342148. 